\title{
WARTOŚCI RELEWANTNE W SPOLECZNYM ŚWIECIE AKTORÓW POLSKICH PUBLICZNYCH TEATRÓW DRAMATYCZNYCH - W ŚWIETLE WYBRANYCH UJĘĆ TYPOLOGICZNYCH
}

\begin{abstract}
Abstrakt. Celem artykułu jest analiza wypowiedzi aktorów polskich publicznych teatrów dramatycznych mająca prowadzić do rekonstrukcji systemu aksjologicznego ukierunkowującego ich działania. Ramy teoretyczne wyznacza typologia wartości zaproponowana przez przedstawiciela fenomenologii Maxa Schelera (wartości hedonistyczne, witalne, duchowe - poznawcze, estetyczne i moralne - oraz religijne) (Scheler 2004; Tatarkiewicz 1990: 219). Leon Dyczewski rozwinął typologię Schelera, dodając jeszcze wartości materialne i wartości socjocentryczne (Dyczewski 2009: 193). Takie tematyczne uporządkowanie pozwoliło mi na wskazanie wartości istotnych zarówno w życiu osobistym, jak i zawodowym polskich artystów teatralnych. Wykorzystałam zarówno źródła zastane (opublikowane wywiady dziennikarskie z aktorami i reżyserami), jak i wywołane (przeprowadzone przeze mnie wywiady swobodne z polskimi aktorami).
\end{abstract} i działań.

Słowa kluczowe: aktorzy polskich publicznych teatrów, wartości jako ukierunkowanie dążeń

\section{Wstęp}

Omówienie wartości istotnych w społecznym świecie aktorów publicznych teatrów dramatycznych rozpocznę od prolegomeny do interesującego mnie zagadnienia. Wartości ,ukierunkowują ludzkie pragnienia i działania oraz są podstawą oceny wszystkiego, co człowiek myśli, czego pragnie i co czyni. Dzięki wartościom może określać, co jest dobre, a co złe" (Dyczewski 2009: 186). Wartości to przekonania, zasady, normy, ideały, idee, postawy, ale i wytwory, obiekty. W literaturze przedmiotu (w filozofii i w naukach społecznych) istnieje wiele definicji i typologii wartości (m.in. W. Tatarkiewicz, N. Hartmann, R. Ingarden, W. Stróżewski, S. Ossowski, J. Tischner, S. Kowalczyk, J. Gajda, H. Kurczab,

* Katedra Socjologii Sztuki i Edukacji, Instytut Socjologii, Wydział Ekonomiczno-Socjologiczny Uniwersytetu Łódzkiego, e-mail.emilia.zimnica@uni.lodz.pl 
J. Puzynina, M. Misztal, A. Pawełczyńska, A. Tyszka, C. Kluckhohn, M. Scheler). Niektóre definicje wartości mają charakter przedmiotowy (wartości jako cechy obiektów materialnych i niematerialnych), niektóre ujęcia mają charakter podmiotowy (związane są ze świadomością człowieka). W pierwszym przypadku wartość jest fenomenem zewnętrznym wobec jednostki, w drugim fenomenem psychicznym. W fenomenologii Schelera wartości mają charakter obiektywny, istnieją niezależnie od podmiotu, są właściwościami świata rzeczywistego. W socjologii dominuje relacjonalne ujęcie wartości (relacja podmiotu wobec przedmiotów świata zewnętrznego). Wartości stymulują zachowania jednostek i zbiorowości, są ważnym spoiwem grupowym. W polskiej socjologii użyteczna poznawczo jest typologia Stanisława Ossowskiego, który wyróżnił wartości uznawane, odczuwane, codzienne i uroczyste (Ossowski 1967: 71-101). Wartości uznawane dotyczą przedmiotów, którym przypisujemy wartość obiektywną, które cenimy ze względu na jakieś ich własności. Ważne jest tu przekonanie, że są one „godne pożądania" i powinniśmy na nie reagować. Wartości odczuwane związane są z przedmiotami dla nas atrakcyjnymi, autentycznie pociągającymi, angażującymi nasze emocje i intelekt. Według Ossowskiego, możliwy jest dysonans między tymi wartościami, bowiem możemy uznawać wartość pewnych obiektów (np. koncertu symfonicznego), ale jednocześnie nie odczuwać bezpośrednio ich atrakcyjności (tamże: 74). Inne rozróżnienie dotyczy wartości uroczystych i codziennych. Pierwsze silnie angażują emocjonalnie, są szczególnie cenne dla nas osobiście bądź szanowane przez środowisko społeczne (np. uczestnictwo w uroczystej premierze teatralnej, nagroda teatralna), drugie mają charakter prywatny i mały rezonans społeczny. W społecznym świecie artystów teatralnych wartością uznawaną jest twórczość artystyczna, która jest jednocześnie wartością odczuwaną. Jeszcze intensywniej odczuwane są pochwały środowiskowych liderów opinii, pozytywne recenzje krytyków i akceptacja widzów nieprofesjonalnych. Wartością codzienną może być satysfakcja związana ze współtworzeniem na próbach ciekawego spektaklu, natomiast wartością uroczystą świętowanie benefisu czy wyjazd na ważny festiwal teatralny.

Władysław Tatarkiewicz ujmował wartość jako własność rzeczy lub samą rzecz posiadającą tę własność (Tatarkiewicz 1986: 76). W praktyce społecznej ujmujemy wartości jako obiekty (miejsca, przedmioty, osoby), jako normy (reguły zachowań) i jako cele (preferowane stany rzeczy) (Jałowiecki 1978: 151). Twórcy teatralni $\mathrm{w}$ wywiadach wypowiadają się o wartościach w każdym z trzech powyższych znaczeń. W pierwszym przypadku mówią np. o swoich mistrzach, którzy „nauczyli ich teatru”, o szkole teatralnej, która przygotowała ich do rzetelnego wykonywania zawodu; w drugim odwołują się do określonych w kodeksie pracy i do niepisanych reguł obowiązujących $\mathrm{w}$ działaniach artysty teatralnego; w trzecim do standardów kształtujących współczesne życie teatralne i oceniają status quo. 


\title{
2. Aksjologiczny wymiar działania w społecznym świecie aktorów ${ }^{1}$
}

\author{
Jak słusznie zauważa Anna Kacperczyk:
}

\begin{abstract}
Wartości ujawniają się w działaniu, gdy ludzie podejmują decyzje co do swego postępowania. Ujawniają się w sposobie odgrywania ról, w konkretnych czynnościach, do których, jako badacze, często mamy dostęp jedynie pośrednio - poprzez narracje aktorów, obserwacje ich zachowań lub analizę dyskursów pojawiających się na arenach. W uzyskiwanych wywiadach i materiałach opisujących czyjeś działania stykamy się z wartościami w postaci rekonstruowanych uzasadnień samych aktorów, którzy samodzielnie (lub z naszą pomocą) usiłują ustalić, co nimi kierowało i dlaczego postępowali tak, a nie inaczej. W formułowanych przez nich ex post rekonstrukcjach własnych motywów, w dyskursach na arenach zawsze jednak udaje się odsłonić wartości jako najważniejsze punkty orientacyjne na mapie ludzkich działań (Kacperczyk 2016).
\end{abstract}

Na podstawie wypowiedzi aktorów zrekonstruuję dominujące w ich społecznym świecie wartości, ukierunkowujące ich ,pragnienia i działania”, porządkując je zgodnie z typologią Maxa Schelera (uzupełnioną przez Leona Dyczewskiego)². Rozpocznę od wartości socjocentrycznych, ponieważ aktorzy najczęściej przywoływali je w dyskursie, podkreślali ich znaczenie w życiu osobistym i w pracy zawodowej, następnie omówię wartości witalne, dalej duchowe (poznawcze, estetyczne i moralne) i religijne. W koncepcji Schelera wyodrębnione są jeszcze wartości hedonistyczne (a Dyczewski dodaje wartości materialne), one z pewnością są także relewantne w społecznym świecie aktorów, jednak w oficjalnych wypowiedziach nie są eksponowane (można się domyślać, że pozostają w sferze tego, co ważne, ale niewypowiedziane). Wyjaśnieniem może być hierarchizacja wartości wprowadzona przez Schelera, występuje u niego gradacja: najniżej umieszcza on wartości hedonistyczne, dalej witalne, za nimi sytuuje wartości duchowe i religijne ${ }^{3}$. Aktorzy wolą mówić o wartościach związanych z wykonywaną profesją, a także o wartościach powszechnie cenionych i uznawanych. Trudniej im się przyznać do orientacji hedonistycznej i materialnej, z pewnością nierzadko wyznaczających kierunek ich działań w społecznym świecie teatru.

${ }^{1}$ Aktorzy polskich publicznych teatrów dramatycznych nie ograniczają się do występów na scenie, zdecydowana większość z nich uczestniczy także w projektach pozateatralnych, grają w filmach, serialach, występują w reklamach. Moi rozmówcy nie rozdzielają tych aktywności, łącznie ujmują aksjonormatywne ramy własnych działań zawodowych i pozazawodowych.

${ }^{2}$ Warto wyjaśnić, dlaczego w tekście zamieszczonym w piśmie socjologicznym wykorzystuję koncepcję filozofa, Maxa Schelera (1874-1928) (kojarzonego z aprioryzmem etycznym i obiektywizmem aksjologicznym). W artykule intencjonalnie abstrahowałam od problemu sposobu istnienia wartości, natomiast poszukiwałam syntetycznej typologii, która mogłaby nadać teoretyczne ramy mojej wypowiedzi i uporządkować niezwykle bogaty materiał empiryczny. Takie warunki w pełni spełniła klasyfikacja Schelera (uzupełniona przez polskiego socjologa), dlatego uznałam ją za optymalną i możliwą do aplikacji w tekście socjologicznym.

${ }^{3} \mathrm{~W}$ fenomenologii Schelera „wartości witalne są wyższe od hedonistycznych, duchowe od witalnych, religijne od duchowych. Są wyższe same przez się, a nie dlatego, że my je wyżej cenimy. Jakiekolwiek weźmiemy kryterium - trwałość wartości czy głębię zadowolenia, jakie dają - wszystkie potwierdzają tę hierarchię" (Tatarkiewicz 1990: 221). 


\section{Wartości socjocentryczne}

Nie sposób oddzielić wartości istotnych dla działania podstawowego od aksjologicznego wymiaru codzienności aktorów, ponieważ sfera zawodowa łączy się ściśle ze sferą prywatną, np. fakt posiadania rodziny wpływa na zawodowe funkcjonowanie aktora. Rodzina to podstawowa wartość w życiu Polaków (por. Komunikaty CBOS: Wartości i normy w życiu Polaków; Co jest ważne, co można, a czego nie wolno - normy $i$ wartości w życiu Polaków) $)^{4}$. Nie przeprowadzono reprezentatywnych badań na temat dominujących wartości w życiu aktorów polskich teatrów dramatycznych, niemniej z dużym prawdopodobieństwem można stwierdzić, że zachodzi tu homologia z systemem wartości polskiego społeczeństwa. Dla moich respondentów rodzina jest istotną, rudymentarną wartością (niektórzy podkreślają, że ważniejszą od pracy). Aktorzy chętnie mówią o bliskich, którzy dają im oparcie, dystans do problemów zawodowych, poczucie prawdziwego spełnienia. Nieraz przeciwstawiają ułudę aktorstwa „prawdziwemu życiu”, realne problemy codzienności konfrontują z zawodowymi. Konstatują, że to właśnie rodzina nadaje wszystkiemu właściwe wymiary:

Rodzina zawsze była dla mnie celem. Szukam spokoju, oczyszczenia, opoki w rodzinie. Trzeba zając się czymś normalnym, co jest prawdziwe, ważne. Jestem odpowiedzialny za życie. Nie jestem dobrym ojcem, ale cały czas mnie to sprowadza na ziemię (Wywiad nr 7).

Miałbym samego siebie oszukiwać, grać przed sobą, że najważniejsza jest scena? No nie. Nie czuję, żeby role dawały mi takie poczucie spełnienia, żebym mógł powiedzieć: „O! Tutaj to mi się udało!”. A z dzieciakami tak właśnie jest. Są fantastyczne! I najważniejsze” (A16: 90).

W wypowiedziach artystów występują liczne emocjonalnie nacechowane określenia odnoszące się do domu i rodziny: „rodzina to świętość”, „moje królestwo", „ładowanie akumulatorów”, „życie rodzinne daje mi równowagę i sens”, „dla mnie założenie rodziny i urodzenie dziecka to jest absolutnie priorytet” itd. Może z powodu specyfiki zawodu, który de facto nie sprzyja życiu rodzinnemu, pojawia się tak wiele deklaracji na ten temat. Życie aktora nie jest „udomowione”, wymaga gotowości do pełnego podporządkowania się pracy. Wielu artystów „żyje na walizkach", wielu dojeżdża do Warszawy na castingi, zdjęcia (udział w serialu, filmie). Młoda aktorka przyznaje, że łączenie intensywnego zaangażowania zawodowego z prowadzeniem domu jest niemożliwe:

Wynajęłam mieszkanie w Warszawie i to była próba, przed którą stanęliśmy jako rodzina, Antoś miał wtedy trzy lata. Żyłam w rozdarciu, byłam potwornie przemęczona. Po 14 godzinach zdjęć wsiadałam w pociąg i jechałam do domu, choćby na trzy godziny, żeby zobaczyć syna. I znów pociąg, prysznic i na zdjęcia. Nie da się długo tak działać (A18: 56).

${ }^{4}$ Dla 97\% respondentów najważniejsze jest zdrowie, a dla 95\% szczęście rodzinne, w tym $83 \%$ badanych uznaje je za bardzo ważne. Praca zawodowa jest istotna dla $80 \%$ badanych, w tym bardzo ważna dla $40 \%$. 
Podobnie jak wielu innych artystów, także i ona podjęła decyzję o przeprowadzce $\mathrm{z}$ rodziną do stolicy na stałe:

„Jestem w stanie bardzo dużo oddać innym, rodzinie. I widzę w tym wartość. Bo to naprawdę wielki dar od losu, że ich mam, czuję się za nich odpowiedzialna. Nie muszę umrzeć na scenie jako aktorka" (A18: 58).

Osoby bliskie ułatwiają zachowanie dystansu do roli zawodowej, nie pozwalają na jej fetyszyzację - znana artystka teatralna metaforycznie mówi o swoim macierzyństwie, że jest w niej „,́́cianą nośną”, ,jest czymś immanentnym i prawdziwym”, co w trudnych sytuacjach było źródłem jej wewnętrznej siły (R3: 56). Rodzina jest w społecznym świecie aktorów wartością odczuwaną i uznawaną, zaspokaja potrzebę bliskości, bezpieczeństwa, miłości. Z drugiej strony jest też wartością szczególnie ,zagrożoną”, bo tryb pracy w społecznym świecie teatru przeszkadza w harmonijnym konstruowaniu rodzinnego życia.

Inną cenną wartością socjocentryczną uznawaną powszechnie przez artystów jest przyjaźn. Długoletnia praca w tym samym teatrze sprzyja bliskim relacjom interpersonalnym, ale ,przyjaźnie”, jakie nawiązują aktorzy podczas współpracy na planie filmowym, czy w ramach realizacji pozateatralnych projektów, zazwyczaj trwają krótko i kończą się wraz z zakończeniem wspólnych działań. Można zatem mówić o więziach społecznych generowanych w trakcie kooperacyjnych aktywności, czasem intensywnych, ale niestety powierzchownych, nieustrukturalizowanych, podatnych na zerwanie. Brak możliwości kontynuowania spotkań bezpośrednich, pojawienie się nowych ludzi wraz z nowymi projektami, skutkuje „wysoką stopą śmiertelności" przyjaźni zawodowych. Toteż wielu aktorów ceni przyjaźnie pozaśrodowiskowe, niezogniskowane wokół działania podstawowego, trwające od dzieciństwa, ,przez całe życie, od przedszkola”. Wartość trwałej przyjaźni jest trudna do przecenienia:

Ta moja przyjaźń jest wyjątkowa i bardzo wierna, jest jak skarb. Nie musimy spotykać się codziennie, ba, czasem nie widzimy się miesiącami i nic między nami się nie zmienia. Wydaje mi się, że wartością tej przyjaźni jest wspólnota doświadczeń. Ale to chyba wtórna rzecz... Wartością pierwotną jest zaufanie i poczucie, że możemy na sobie polegać, liczyć na siebie, a z drugiej strony coś takiego, nie wiem, czy się jasno wyrażę, że nie musimy nic, że to nie na tym polega, że jak mi będzie źle, to do niego zadzwonię. To jest pokrewieństwo, jeśli nie dusz, to na pewno istnienia w świecie. A także poczucia humoru, którego posiadanie dla mnie jest ogromnie ważne (A26: 98).

Niektórzy moi przyjaciele to aktorzy, ale oni mają takie samo podejście do zawodu jak ja: czyli praca, praca, zawodowstwo. Mój najlepszy przyjaciel to przyjaciel z liceum, z Poznania. Trzymamy się od 17 lat. Ja lubię mieć wybór. To byłoby straszne, gdyby miejsce pracy determinowało moje kontakty towarzyskie. Ja lubię mieć wybór (Wywiad nr 10).

W kolektywnym działaniu niezmiernie istotne są wartości socjocentryczne. Szczególnie starsi aktorzy, spełnieni zawodowo, podkreślają ich znaczenie, cenią dobre relacje międzyludzkie, możliwość współpracy z sympatycznymi 
i kompetentnymi ludźmi. Czasem ich decyzja o przyjęciu propozycji zawodowej uzależniona jest od towarzystwa osób, z którymi trzeba będzie spędzić jakiś czas:

Kiedyś chciałem zagrać Makbeta, Hamleta itp. Teraz ważniejsze jest dla mnie z kim. Każda rola to kilka miesięcy prób, a serial - kilka lat pracy. Jak więc widzę, że z gościem będę się użerać, bo on nie ma zielonego pojęcia, czego ode mnie chce, czego od siebie i co chce ludziom przekazać, mówię: „Nie, dziękuję” (A16: 87).

\section{Wartości witalne}

Dyczewski zwraca uwagę na „sytuacyjny kontekst wyboru wartości” (Dyczewski 2009: 191). Aktorzy jako grupa zawodowa pewne dobra cenią bardziej niż pozostali członkowie społeczeństwa. Przywiązują dużą wagę do wartości witalnych - dla nich podstawowym instrumentem pracy jest własne ciało, a troska o zdrowie fizyczne jest niezbędna, by dobrze wypełniać swoją zawodową rolę. Aktorzy podejmują wiele działań, by zachować dobrą formę psychofizyczną, chodzą na siłownię, basen, do sauny, biegają, niektórzy startują w maratonach:

Biegam, endorfiny się wytwarzają, ale nie jestem maratończykiem. Ja to robię w ciszy, samotności (Wywiad nr 7).

I sport - codziennie - nordic walking, basen. Długo grałem w siatkówkę, ale teraz nie mam czasu. Odpoczynek - to sport. A jak mam taki full wypas, to jadę do Łagiewnik, chodzę tam z kijami, potem jadę na Nową Gdynię, pływam pół godziny, potem jadę na Falę, bo tam jest genialny świat sauny (uwielbiam saunę na podczerwień) (Wywiad nr 9).

W trosce o higienę psychiczną niektórzy artyści praktykują medytację, która jest dla nich źródłem spokoju, koncentracji, dystansu do własnego „ego”. Jeden z moich rozmówców zainteresował się buddyzmem:

Jest to buddyzm świecki, tybetański. Nie zakładam kimona. Medytuję sam i jeżdżę dwa, trzy razy do roku... byłem trzy tygodnie w Nepalu (to był ważny dla mnie wyjazd). Medytowałem, to było ważne przeżycie. Buddyzm jest pragmatyczny i złożył mi się z teatrem. Ja też bardzo pracuję w teatrze nad improwizacją, bo to mnie otwiera. Cały czas pilnuję, gdy gram 75-80 przedstawienie, aby traktować je jako nową rzecz, jako „tu i teraz”. Buddyzmem zainteresowałem się dlatego, że miałem duże kłopoty z koncentracją na scenie, byłem w postaci, ale wypadałem... Zacząłem chodzić na spotkania w Łodzi. To była praca nad ogarnianiem umysłu, akceptacja faktu, że pojawiają się takie, a nie inne myśli, przyzwolenie na to. To jest tylko myśl, nie mam na nią wpływu i mogę ją zatrzymać albo dam jej odpłynąć (Wywiad nr 10).

Bardzo wielu aktorów podróżuje, jest to sposób na oderwanie się od zabieganej codzienności, „zresetowanie się” i nabranie sił przed kolejnymi zadaniami. Sugestywnie mówi o tym Ewa Kasprzyk: 
Kiedy tak przelatuję nad Phuket, Bangkokiem, Delhi, Bukaresztem, Paryżem, to wydaje mi się, że strzepuję kurz z tego zasiedzenia się, z tej rutyny, z tej „19.30 kurtyna w górę”. Z tego malowania się, mizdrzenia, oczekiwania aplauzu - po prostu jestem tu, w powietrzu [...]. Jeśli znudziło ci się cały czas udowadniać, że jesteś dobry, cały czas do czegoś dążyć - zdobywać, pomnażać, osiągać, porównywać, nadawać, przekonywać, ścigać się, być skrępowanym, przebiegłym, ubranym, czystym, zadbanym, umalowanym, „wymanikiurowanym”, „wypedikiurowanym", spiętym, skoncentrowanym na miejscu, w pierwszej linii, na starcie, w biegu, w pośpiechu, na obrotach, po pięciu kawach, paczce papierosów, na skraju, w konkurencji albo już poza nią, na castingu, w obsadzie, w serialu, bez pieniędzy, na kredycie, na „bezlocie”, na odwyku, na „odkrzyku” - wyjedź do Tajlandii na Muay Thai, czyli tajski boks” (Kędziak/ Kasprzyk: 8-9).

Nie wszystkich pociągają egzotyczne kraje i ,tajski boks”, niektórzy artyści remedium na stresy znajdują na polskiej prowincji:

Mam taką chałupkę na wsi, w lasku, tam troszkę ją odnowiłem, bo to stało od lat... Starzeję się i coraz częściej tam lubię jeździć... Moja żona się śmieje, a ja już mam cztery pnie przygotowane... sosnowe. Ja teraz wracam do rzeźby, prymitywne rzeczy robię, proste konstrukcje (zapis spotkania Aktora z publicznością, Aleksandrów Łódzki).

Aktorzy mają wiele pasji pozateatralnych - fotografują, piszą scenariusze, muzykują, malują, czytają książki itd. Nawiązując do typologii wartości opracowanej przez Schelera, można powiedzieć, że pasje, oprócz tego, że należą do kategorii wartości witalnych (przyczyniają się do przyrostu sił życiowych), są także wartościami hedonistycznymi (sprawiają przyjemność) i duchowymi (estetycznymi i poznawczymi). Deklarowane wartości witalne w zasadzie nie różnią aktorów od typowych przedstawicieli klasy średniej, jednak jest jedna rzecz, która ich z pewnością wyróżnia - częste uczestnictwo w terapiach psychologicznych. W wielu wywiadach pojawia się ten wątek, oto wybrane wypowiedzi:

Od trzech miesięcy chodzę na terapię. Nie masz pojęcia, ilu ludzi w moim wieku, z mojej branży spotyka się w kolejce na terapię. Znany aktor, znany reżyser, dziennikarz... (R5: 52).

Ja dopiero po studiach zaczęłam chodzić na terapię psychologiczną, chodziłam dwa lata, bardzo mi pomogła. Pomogła mi uodpornić się na życie. Nie jestem chora psychicznie, ze mną jest wszystko w porządku. To jest kwestia poznania siebie, mechanizmów, swoich schematów myślenia i zachowań, poznania siebie, tego, co chcę zmienić, a nie umiem. Tylko dzięki temu mogę być lepszą aktorką, bo lepiej siebie znam. Żałuję, że tego nie było na studiach, zdecydowanie (Wywiad nr 4).

Można odnieść wrażenie, że istnieje moda na terapie w środowisku teatralnym (raczej wśród młodszych przedstawicieli tego środowiska), mówią o nich w dziennikarskich wywiadach prasowych przede wszystkim kobiety: Agnieszka Glińska, Anna Dereszowska, Ilona Ostrowska i wiele innych aktorek. Niektóre przyznają expressis verbis, że dzięki terapii wyszły z poważnej depresji i polecają innym właśnie taki sposób radzenia sobie z problemami. Co ciekawe, swoje 
wypowiedzi ujmują w kategoriach misyjności - starają się propagować terapię psychologiczną w społeczeństwie i przekonać innych do tej praktyki:

Bez terapii bym sobie pewnie nie poradziła. Gabinet terapeuty to takie miejsce, które pomaga nie tylko poszerzyć świadomość, ale również przeżywać. Przez te lata wiele osób namówiłam na terapię, śmieję się, że mam misję szerzenia wiedzy o psychoterapii, tłumaczę znajomym bliższym i dalszym, co z tego może być dobrego (R3: 56).

Artystka zdaje się zapominać o czynniku ekonomicznym - w społeczeństwie polskim istnieje nie tylko bariera obyczajowa, ale i finansowa. Polacy nie chodzą na terapie, bo ich po prostu na to nie stać - państwowa służba zdrowia w tej dziedzinie jest wyjątkowo niewydolna, nieefektywna.

Co jeszcze robią aktorzy (szczególnie aktorki) w ramach realizacji wartości witalnych? Odżywiają się ekologicznie, wykonują ćwiczenia fizyczne, stosują diety, poprawiają urodę w gabinetach kosmetycznych, itp. Dla porządku odnotować trzeba, że moda na zdrowy tryb życia nie dotyczy wszystkich aktorów, niektórzy uznają co prawda wartość „,witalności”, ale ponieważ gimnastyka czy wysiłek na siłowni nie jest dla nich wartością autoteliczną, wartości tej nie realizują na co dzień. Wypowiedź Krzysztofa Globisza z pewnością nie należy do wyjątkowych:

Trzeba kochać ciało [...]. Wiele zrobiłem w swoim życiu, żeby je zniszczyć. To sprawy związane z ćwiczeniami, grą, eksploatacją w teatrze. Brak higieny, dbania o siebie doprowadził do tego, że mam, na przykład, kłopoty z kolanami (Globisz 2015).

\section{Wartości poznawcze}

Aktorzy dzielą się na tych, którzy intensywnie pracują i nie mają specjalnie czasu na rozwój intelektualny, czytanie książek, oglądanie przedstawień w swoim i w innych teatrach, zgłębianie tajemnic bytu (realizują się w działaniu), i tych, którzy wciąż inwestują w rozwój sfery poznawczej, wzbogacając w ten sposób własne aktorstwo. To kwestia priorytetów i możliwości, choć z pewnością niektórzy starają się łączyć obie sfery. Artyści, którzy nie narzekają na niedobór ról, starają się wykorzystać nadarzające się okazje, bo w tym zawodzie nic nie jest stałe i dobra passa zawsze może się skończyć. Aktorzy zatrudnieni na stanowisku nauczycieli akademickich siłą rzeczy muszą być wrażliwi na sferę wartości poznawczych, na teoretyczne, naukowe ugruntowanie wiedzy o kulturze, sztuce, teatrze. Niektórzy buntują się, gdy traktowani są z nonszalancją, gdy przypisuje się reprezentowanej przez nich grupie zawodowej hermetyczność intelektualną: „Nie godzę się z obraźliwymi słowami, które czasem słyszę: «Przecież to tylko aktorka. Mówi całe życie cudzym tekstem. Prywatnie nie ma nic do powiedzenia»" (Łabonarska 2015). 
Aktorzy są dobrymi psychologami, zgłębiają tajniki ludzkiej psychiki, uczą się empatii, postrzegania różnych aspektów tej samej sprawy. Charakterystyczna jest wypowiedź młodej adeptki sztuki teatralnej:

„Jak jest konflikt, to jestem w stanie wczuć się w uczucia i rozumieć argumentację obu stron i usprawiedliwić obie postawy. Ja muszę się jeszcze siebie zapytać, jakie jest moje zdanie" (Wywiad nr 4).

O uwrażliwieniu środowiska na wartości poznawcze zaświadczają też inne wypowiedzi:

Aktor ma całe życie się rozwijać, ma pracować nad ciałem, ma pracować nad wyobraźnią, ma czytać książki, otwierać nowe szufladki, bo to pomaga w budowaniu spektaklu (Wywiad nr 9).

Młodzi aktorzy (do 30 lat) muszą podejmować tysiące decyzji, czy tutaj, czy tam. Sytuacja filmu, reklamy jest dla nich podstawowa. Problem jest tylko z logistyką... Pogoń za „tu i teraz” nie daje im możliwości zagłębienia się w książkach. Dlatego na próbach staramy się pogłębiać temat, oglądamy filmy, dyskutujemy. Starsi aktorzy... dojrzali, mają dużo do powiedzenia, ale nie mają możliwości zaprezentowania tego w innych obszarach kultury. Widzowie tego nie zobaczą. W programach kulturalnych - np. na TVP Kultura w programie «Niedziela z...» może to się pojawi, dopuścimy do głosu aktorów, którzy pokażą, jak wiele mają do powiedzenia. Generalnie nie ma kanałów, możliwości, aby to pokazać (Wywiad nr 15 z dyrektorem artystycznym teatru).

W przekonaniu mojego rozmówcy - praktyka teatralnego - w kwestii wartości poznawczych istotne są społeczne uwarunkowania, a podstawowe znaczenie ma czynnik demograficzny. Starsi aktorzy, edukowani i socjalizowani w czasach przedtransformacyjnych, mogą pochwalić się gruntowną wiedzą humanistyczną, młodzi natomiast mają mniej czasu na rozwój intelektualny ze względu na signum temporis: poliaktywność, dywersyfikację działań zawodowych. Uczestniczą symultanicznie w tak wielu projektach, że siłą rzeczy zaniedbują sferę intelektualną.

\section{Wartości estetyczne}

Zdaniem polskiego fenomenologa, Romana Ingardena, o człowieczeństwie decyduje nade wszystko wyczulenie na wartości etyczne (dobro, prawda etc.) i estetyczne (piękno, wzniosłość, wdzięk etc.) (Ingarden 1972). Przygotowywanie spektakli i publiczna ich prezentacja stanowią realizowanie wartości estetycznych w praktyce. Twórcy teatralni różnią się smakiem estetycznym, jedni preferują komizm, inni tragizm, jeszcze inni operują ironią lub groteską. Chociaż różnie pojmują piękno, łączy ich stwarzanie dzieła sztuki, które oddziałuje na odbiorców walorami literackimi, plastycznymi, muzycznymi i prowadzi ich do przeżycia estetycznego. W teatrze wiele zależy od kunsztu wykonawczego aktora, który musi sprawnie poruszać się $\mathrm{w}$ ramach proponowanej przez reżysera estetyki. 
O wartościach estetycznych trudno dywagować językiem socjologicznym, należy - za teoretykami - przyjąć a priori, że stanowią one differentia specifica każdego dzieła. Można natomiast spierać się (i aktorzy chętnie w tym uczestniczą), jakie kategorie estetyczne znajdą rezonans u odbiorców, jakie powinno być oblicze współczesnego teatru. Jako egzemplifikację warto przytoczyć kilka zróżnicowanych wypowiedzi:

Sztuka musi być zrozumiała, bo mamy chaos, bałagan, po co zniekształcać autora, a dzisiaj gotowi są grać sztukę od tyłu. Sztuka jedna, złożona z czterech sztuk Szekspira. To co ten widz biedny ma zrozumieć $\mathrm{z}$ tego? [...] Przeniesiono bezmyślnie sztuki brutalistów z Zachodu i poszła fala u nas. A każdy stara się być oryginalny i zafunkcjonować (Spotkanie z Aktorem, Aleksandrów Łódzki).

Widzowie generalnie $\mathrm{z}$ oporem odbierają wszystko, co jest inne od ich konserwatywnych oczekiwań, problem z odbiorem teatru istnieje. Nawet ci, co regularnie przychodzą, nie zauważają, że język teatru się zmienia. Widz nie jest przygotowany, musi przyswoić ten nowy język. Co innego zobaczymy w Muzeum Narodowym w Krakowie i inny rodzaj sztuki w Muzeum Sztuki Nowoczesnej. W teatrze ludzie nie zdają sobie sprawy z tego, że język teatru ewoluuje. Spektakl-esej nie jest zrozumiany, jest trudny w odbiorze, toteż ważne są dodatkowe działania w teatrze - edukacyjne, kierowane do szerokiego grona widzów. Trzeba pokazać, że trudno wymagać od reżyserów, którzy mają po 25 lat, by mówili językiem innej epoki. Na nich również oddziałuje sfera medialna, komputery, Internet, telefony komórkowe. To na nich rzutuje (Wywiad $\mathrm{nr} 15 \mathrm{z}$ dyrektorem artystycznym).

\section{Wartości moralne}

Maria Ossowska jest autorką znanej książki na temat funkcjonowania w społeczeństwie norm moralnych (w obronie biologicznego istnienia, w obronie godności, niezależności, prywatności, służące potrzebie zaufania, strzegące sprawiedliwości i łagodzące społeczne konflikty). Zachowania altruistyczne, allocentryczne są niezmiernie ważne z punktu widzenia zbiorowości, przyczyniają się do jej konsolidacji i stworzenia ładu, zwiększają efektywność działań. „Cnoty miękkie na straży pokojowego współistnienia” - obejmują m.in. życzliwość, braterstwo, miłość bliźniego (O ssow ska 1985). W dyskursach aktorów pojawia się refleksja na temat reguł zachowań i „pożądanych stanów rzeczy”, które są istotne zarówno w ich życiu zawodowym, jak i prywatnym: wiara w siebie i uczciwość (A17: 12), szczerość, otwartość, lojalność (A17: 12), wrażliwość na potrzeby innych (A38b), sumienność, poczucie obowiązku (A41: 25), empatia i niekrzywdzenie innych (A19: 115), odpowiedzialność (R3: 57). Artyści z reguły obdarzeni są ponadprzeciętną wrażliwością, która ma odzwierciedlenie nie tylko w sposobie traktowania innych ludzi, ale także przekłada się na ich stosunek do zwierząt. Albert Schweitzer, niemiecki teolog, filozof i lekarz, mawiał, że współczucie wobec wszystkich istot jest najlepszym sprawdzianem człowieczeństwa. Niektórzy artyści właśnie 
względami humanitarnymi motywują swój wegetarianizm (m.in. Maja Ostaszewska, Kinga Preis): „Świadomość tego, w jakich to wszystko odbywa się warunkach: cierpienie, połamane nogi i dzioby, ta bezsensowna, nafaszerowana antybiotykami śmierć odebrały mi wolę jedzenia mięsa" (A34: 47).

M. Scheler, dla którego wartości duchowe (poznawcze, estetyczne i moralne) umieszczone były wysoko w hierarchicznie skonstruowanym systemie aksjologicznym, osobne i szczególne miejsce poświęcił problematyce wolności (Scheler 2004). Wolność jest cenioną uniwersalną wartością, relewantną w społecznym świecie artystów, jest też szczególnie istotna dla aktorów polskich publicznych teatrów dramatycznych. Warto w tym miejscu wspomnieć o badaniach psychologicznych, jakie przeprowadziła wśród wybitnych polskich aktorów Barbara Mróz (2008), z których wynika, że „wolność osobista” została przez nich umiejscowiona najwyżej spośród osiemnastu walorów, jakie mieli hierarchicznie uszeregować. Autorka stwierdziła, że aktorzy „są grupą bardzo specyficzną właśnie poprzez taki wybór tej wartości", ponieważ inne badane przez nią grupy zawodowe nie podkreślały aż tak bardzo znaczenia niezależności w działaniu. Moim zdaniem, wyjaśnieniem tego faktu może być deficyt owej wartości w zawodzie aktora. Jak wynika z wywiadów, autonomia działań twórczych jest wielkim luksusem, na który niewielu aktorów może sobie pozwolić. Taki stan wolności twórczej osiągnęła np. Krystyna Janda, która zrezygnowała z pracy w teatrze publicznym (i dopiero jako dyrektorka prywatnych teatrów może podejmować niezależne decyzje). Jednak innym artystom, których zatrudnia we własnych placówkach, stawia granice, przyznaje się też do „cenzurowania sztuk”: „W moim teatrze pozytywna postać nie krzyczy: «Kocham ćpać». Wykluczone. Dopuściłam się kilkakrotnie tego rodzaju ingerencji, ponieważ nie chcę, żeby ze sceny padały słowa, które mnie bolą, albo których nie akceptuję" (Janda 2015: 175). Inny aktor, zatrudniony w publicznej instytucji, stosuje w praktyce autocenzurę - deklaruje, że z zasady nie bierze udziału w spektaklach, w których występują wątki związane z seksem, alkoholem, narkotykami, nie lubi też publicznie wypowiadanych przekleństw $(\mathrm{Ku}-$ szewska 2015: 64). Zdarza się, chociaż niezmiernie rzadko, rezygnacja z pracy $\mathrm{w}$ profesjonalnym teatrze z powodów światopoglądowych ${ }^{5}$.

Oficjalna cenzura państwowa skończyła się wraz z transformacją ustrojową, de facto istnieją jednak przykłady ingerowania urzędników państwowych w repertuar teatrów, najczęściej w przypadku naruszania przez grupy artystyczne wartości uznanych za nienaruszalne (wartości religijne, narodowe, tabu kulturowe). Co prawda, zakazy nie są tak restrykcyjne jak w Rosji (m.in. zakaz używania przekleństw na scenie), jednak artyści odbierają je jako zamach na ich wolność twórczą, swobody obywatelskie i demokrację (m.in. A55: 34). Dyskusja środowiska

${ }^{5}$ Czasem aktor odchodzi z zawodu, kiedy stwierdza niekompatybilność własnych ideałów z wymogami ról (choć trzeba przyznać, że jest to sytuacja precedensowa). Przykładem może być Piotr Kowalewski, zob. Ćwiczenia z dykcji, film dokumentalny w reżyserii Jerzego Sztwiertni, Fokus Film Sp. z o.o. 
teatralnego wokół głośnych w Polsce spektakli, określanych jako „skandale teatralne" (Golgota Picnic, Do Damaszku, Śmierć i dziewczyna, Klątwa) pokazuje szczególne uwrażliwienie twórców na sferę wolności artystycznej ${ }^{6}$. Istotą sztuki jest transgresja i testowanie granic, nie można - zdaniem twórców - odmawiać jej pełnej autonomii. Ponadto oczywisty jest podrzędny status aktora wobec reżysera, który ma prawo narzucić aktorowi swoją wizję spektaklu. Niemniej są artyści, którzy dokonują selekcji ról i nie godzą się na pełne podporządkowanie:

Nie będę się wzdragał przed rolą Stalina. Ale nie zagram w sztuce, która go przedstawia jako dobroczyńcę ludzkości (Zapasiewicz 1989: 242).

Nie przyjmuję ról w projektach, które już na poziomie scenariusza kłócą się z moim systemem wartości i gustem. Wiem, że nie będę w stanie tego zagrać. Za żadne pieniądze. W pozostałych przypadkach kryterium jest bardzo proste: motywacja. Jeśli nie mam wątpliwości co do czystości intencji reżysera, rozumiem jego zamysł i mnie to ciekawi, to jestem gotowa na wiele (A52: 33).

Jedna $\mathrm{z}$ artystek teatralnych, która nie miała wpływu na wydźwięk tego, co proponowali reżyserzy w swoich projektach, mocno odczuła potrzebę wolności artystycznej. Zdecydowała się na rozstanie z macierzystym teatrem, przygotowała recital z piosenkami, których treść jest jej bardzo bliska:

Wiem, że mówię dokładnie te rzeczy, które chcę powiedzieć, w sposób, który jest moim sposobem [...]. Może to był rodzaj toksyny teatralnej. Ta obsesja, że muszę przynależeć do grupy, służyć jakiemuś władcy, królowi. Teraz myślę o tym, czego JA chcę, i to prawdziwie rewolucyjne podejście. Nie oglądać się na to, co próbują ci narzucić, iść własną ścieżką przez nikogo niewytyczoną (A39b: 50).

Wolność to samosterowność, nonkonformizm, wielki przywilej i niezaspokojona do końca potrzeba. Aktorzy są rozdarci między koniecznością dostosowania się do innych przy realizacji spektaklu a silną potrzebą zaznaczenia własnej indywidualności:

W tym niezwykłym pędzie, któremu w większości ulegliśmy, w tym bezmyślnym stadzie, dajemy się ponosić w kierunki, które nie są naszymi kierunkami. Boimy się, że jeśli staniemy, to nas to stado stratuje, albo że będziemy jacyś wyraźnie inni na jego tle. Nie, właśnie tak ma nie być, bo każdy człowiek jest odrębny (A31: 101).

Aktor ,etatowy”, zaangażowany w teatrze na czas nieokreślony, powinien przyjąć każdą rolę (wolność jest zatem wartością uznawaną, ale w praktyce nierealizowaną) $)^{7}$. Jego praca uzależniona jest od wielu innych twórców, ponieważ

${ }^{6}$ Problematyce wolności artysty poświęcony jest cały numer „Notatnika Teatralnego" 2017, nr 84-85, dotyczący Klątwy przygotowanej przez Olivera Frljicia w Teatrze Powszechnym im. Z. Hübnera w Warszawie (premiera spektaklu odbyła się 18 lutego 2017 r.).

${ }^{7}$ Zwyczajowo jeden raz w trakcie sezonu może zrezygnować $\mathrm{z}$ wykonania zadania (na podstawie wywiadów autorki tekstu z aktorami polskich publicznych teatrów dramatycznych). 
spektakl to dzieło zespołowe i o ostatecznym efekcie decydują wszyscy uczestnicy tego procesu (w różnym stopniu rzecz jasna):

Niezależny jestem tylko w moim domu, w pewnym jego fragmencie... Zależę od wszystkich, mam czasami wrażenie, że jestem ostatnim małym kółeczkiem zębatym, które dopiera działa, kiedy machina... kiedy dyrektor, kiedy reżyser... (Wywiad nr 7).

W codziennej pracy w teatrze aktor musi pogodzić się z faktem utraty autonomii na rzecz większej całości i mimo wszystko cenić działania, które przynoszą satysfakcję, które są pasją. Istotne dla wielu aktorów są zachowania, które ułatwiają kolektywną pracę (wartości socjocentryczne, mające wpływ na życie grupowe: solidność, punktualność, życzliwość, otwartość na innych). Trzeba z zaangażowaniem wykonywać swoją pracę (pomimo jej minusów), w pełni koncentrować się na aktualnym zadaniu, doceniać możliwość „bycia częścią wartościowych projektów”, szanować widzów - to ważne „etyczne ukierunkowanie" zdecydowanej większości moich rozmówców. Wiele mówią oni o „zawodowej uczciwości”, o profesjonalizmie:

Jest się odpowiedzialnym za coś większego niż tylko za siebie, spektakl jest najważniejszy, muszę być, nie mogę dać powodu, aby ktoś się bał o mnie, że mnie nie będzie, że przyjdę pijany, naćpany... Nie ma takiej możliwości. X odwoływał spektakle z dziwnych przyczyn... Pewnego rodzaju ideały, które wiązały się z pójściem do tej szkoły... jest to misja... bliżej nie wiadomo jaka, ale ideały obowiązują. Nie tylko to jest po to, aby być na pierwszych stronach gazet, aby być popularnym.. Chodzi o to, aby być w jakiejś grupie, tworzyć coś, ważny jest nimb artyzmu, czegoś pięknego (Wywiad nr 7).

Aktorzy doceniają reżyserów, którzy traktują ich po partnersku, podmiotowo, dają im „przestrzeń wolności” w procesie współpracy nad przedstawieniem. Realizacja działania podstawowego z reżyserem omnipotentnym, autorytarnie egzekwującym swoje prawa dominacji, odpowiada nielicznym. O reżyserach, którzy pozwalają aktorowi brać czynny udział w twórczym zmaganiu się z materią teatralną, i w tym sensie poczuć się artystą, moi rozmówcy mówią z wielkim szacunkiem i wdzięcznością.

\section{Wartości religijne}

Wartości religijne znajdowały się na szczycie hierarchii Maxa Schelera, jednak artyści teatralni rzadko dywagują na temat wiary religijnej. Wiara w Boga jest w środowisku „kompletnie niemodna”, stwierdza jedna z aktorek, ale jej kolega deklaruje: „Jestem człowiekiem bardzo wierzącym, praktykującym - czego się nie wstydzę. Choć wstydziłbym się wtedy, gdybym był dewotem" (Ruman 2011: 127). W środowisku aktorskim, podobnie jak w każdym innym, można zaobserwować całe spektrum postaw wobec religii, są wierzący, agnostycy, osoby 
indyferentne religijnie, niewierzący, ale określający siebie jako „poszukujący” $i$ ateiści. Trudno o statystyki, ale z pewnością wiele jest osób wątpiących, niepewnych w wierze.

Elżbieta Ruman przeprowadziła rozmowy z aktorami, którzy znani są w środowisku teatralno-filmowym jako osoby przywiązujące wagę do religii w życiu codziennym (Małgorzata Kożuchowska, Maciej Rayzacher, Teresa Lipowska, Ewa Gorzelak, Jerzy Stuhr, Lidia Bogaczówna-Popiel, Jan Kobuszewski, Olgierd Łukaszewicz, Jerzy Zelnik) (Ruman 2011). Oczywiście, aktorów deklarujących przywiązanie do religii jest więcej, pewnie nie wszyscy chcą na tematy światopoglądowe rozmawiać, choć generalnie są ludźmi otwartymi, przyzwyczajonymi do pytań dziennikarzy ingerujących w ich sferę prywatną. Można pytać, czy wiara ma znaczenie w życiu zawodowym aktorów, czy im pomaga czy też utrudnia funkcjonowanie w zawodzie. Indagowani w tej sprawie artyści stwierdzali najczęściej, że z powodu światopoglądu dokonują selekcji ról, wyznaczają granice, jakich nie chcieliby przekroczyć. Ewa Gorzelak przyznaje się do stosowania autocenzury i zapewnia, że nie jest w tym odosobniona: „Wiem, że są aktorzy, którzy pewnych ról by nie zagrali ze względu na przekonania" (tamże: 85).

Socjologowie zdają sobie sprawę, że deklaracje nie zawsze pokrywają się z rzeczywistymi zachowaniami, jednak Lidia Bogaczówna-Popiel zwierza się, że de facto zdarzyło jej się odrzucić (główną) rolę. Ciekawe, że ona sama nie ma pewności, czy powodem rezygnacji była religia:

Nie wiem tylko, czy to bardziej z wiary wynikało, czy z wychowania... Dotyczyła, powiedzmy sobie, szalenie prywatnej sfery seksualnej... Było to dla mnie nie do przejścia, zarówno w języku, jak i w scenach. Powiedziałam, że absolutnie tego nie przyjmę, bo nie jestem w stanie tego zagrać (tamże: 114).

Podobne postawy polaryzują środowisko, wielu uczestników społecznego świata teatru uważa, że aktor nie powinien utożsamiać się z graną przez siebie postacią i przyjmować każde zadanie: „Postaci, które kreujemy, to przecież nie my!” Niemniej niektórzy artyści mówią o własnym poczuciu odpowiedzialności za przekaz sceniczny, nie chcą być utożsamiani z treściami, które interferują z ich systemem wartości, z ich przekonaniami. Halina Łabonarska jest jedną z tych aktorek, które sprzeciwiają się uczestnictwu w przedsięwzięciach, podważających relewantne dla niej wartości: „«Świętości nie szargać, bo trza, żeby święte były» - to, co pisał Wyspiański, jest wciąż aktualne. Brzydzę się takim zachowaniem i odmawiam, mając poczucie, że to najlepsze, co mogę zrobić" (Łabonarska 2015). Teresa Lipowska, która deklaruje przywiązanie do chrześcijaństwa, stwierdza, że uczciwość w pracy, pełne zaangażowanie w rolę, szacunek dla innych, wypływają z „wartości naczelnej”, czyli z jej wiary: „Bo jeśli ktoś przyznaje się do Boga, który jest Miłością, i chce dobra dla wszystkich ludzi, to chyba musi starać się po prostu dobrze żyć" (Ruman 2011: 65). 
W środowisku aktorskim deklaracja wiary różnie jest przyjmowana, często z niechęcią. Aktorka - katoliczka z przekonania - zwierza się z osamotnienia, niezrozumienia i dyskryminacji:

Na przykład pod koniec lat 90. z tego powodu nie dostawałam żadnych ról. Dowiadywałam się o tym w rozmowach prywatnych. Czasem komunikowano mi to żartem, innym razem bardzo ostro. Nazywano mnie „obrzydliwą konserwą”, z którą nie da się pracować. Na dodatek uważano, że jestem sama sobie winna, bo się na to dobrowolnie decyduję. Był nawet taki moment, że chciano mnie zwolnić, motywując to redukcją etatów (Łabonarska 2015).

Aktorzy niewierzący mówią z kolei o własnych poszukiwaniach duchowych, rozważają pytania egzystencjalne (w sensie filozoficznym), czasem nawet powołują się na autorytet katolickich świętych:

Jan Paweł II napisał taki piękny wiersz, który kończy się słowami: „Przemijanie ma sens, ma sens, ma sens”... „Ma sens” jest trzy razy powtórzone i to mnie zastanowiło. Przemijanie ma sens, bo jeśli my tylko i wyłącznie ograniczymy się do ciała, to jesteśmy zgubieni. Ciało jest naruszalne, kruche, chorowite. To dotyczy wszystkiego, również miłości czy macierzyństwa. Miłość jest silniejsza niż śmierć, bo człowiek umiera, a my nadal go kochamy. To jest nie tylko sprawa wiary, ale też pewnej energii - jeśli ograniczę się tylko do ciała, to gdzie jest mój talent, moje emocje? To po co ja na tej scenie krzyczę, płaczę i wychodzę po spektaklu połamana i obolała? Tam nie gra jedynie moje ciało... tam śpiewa moja dusza, czasem radosne, czasem smutne kawałki, bo nie wszystko musi być wesołe, potrzebna jest chwila refleksji. Są momenty, kiedy dotkliwie odczuwam tę nieznośną lekkość bytu. Kim jestem, po co, na co, dlaczego - ciągle pytam (A12a: 22).

Dla wielu artystów istotny jest rozwój wewnętrzny, a dopiero w dalszej kolejności tzw. kariera i pieniądze. Zdeklarowani antycelebryci nie biorą udziału w banalnych projektach, które wykorzystują tylko ich atrakcyjną fizyczność i nie stanowią poważnego zadania aktorskiego. Szkoda im czasu na bankiety, banalne medialne eventy, wolą przeczytać książkę czy obejrzeć dobry film (m.in. A33: 44). Refleksyjność bywa wspierana działaniami na rzecz innych, aktorzy bez względu na stosunek do wartości religijnych zakładają fundacje lub współpracują z organizacjami pożytku publicznego, angażują się w prace hospicjów. Wszyscy znają działania Anny Dymnej i jej fundacji „Mimo Wszystko”, Ewy Błaszczyk „Akogo?", ale nie tylko one działają w instytucjach non profit. Ewa Gorzelak, po trudnym doświadczeniu, jakim była poważna choroba młodszego syna, założyła Fundację „Nasze Dzieci” przy Klinice Onkologii w Instytucie „Pomnik-Centrum Zdrowia Dziecka”, Maja Ostaszewska współpracuje z Fundacją Międzynarodowy Ruch na Rzecz Zwierząt Viva!, bierze udział w kampaniach przeciwko niehumanitarnemu traktowaniu zwierząt (A55: 34). Czasem swoje przekonania może wyrazić poprzez sztukę: „Cieszę się, że w (A)pollonii Krzysztofa Warlikowskiego mogę mówić 30-minutowy monolog o holokauście zwierząt” (tamże). Mariusz Jakus wspiera fundację swojej żony, Katarzyny Mastalerz-Jakus (Fundacja Rzecznik Praw Rodziców) itd. Aktorka, która jest związana z wrocławskim hospicjum, 
mówi o przeżywaniu właśnie tam „chwil świętych i najważniejszych”. Cieszy ją możliwość „,zrobienia czegoś dobrego. Dania komuś nie tylko pieniędzy, ale też uwagi, czasu, energii” (A34: 48). Dla wielu aktorów altruizm jest wartością uznawaną i odczuwaną, choć nie zawsze realizowaną. Nawet jeśli oni sami nie działają społecznie (na przykład z powodu braku czasu), doceniają prawdziwych społeczników, imponują im ludzie, którzy „,robią coś dobrego dla świata”. Niekoniecznie chodzi tu o spektakularne działania, skupiające uwagę publiczną, ale też o gesty nienagłośnione. Warto podkreślić, że popularność pomaga w zdobywaniu środków finansowych na prowadzenie działalności w organizacjach pozarządowych, potwierdza to m.in. Ewa Gorzelak:

I jest to chyba najsensowniejsze wykorzystanie popularności - pomagać innym [...]. Dobrze jest zobaczyć, że wokół są inni ludzie, że nas potrzebują, że my ich potrzebujemy. Przede wszystkim nie powinniśmy skupiać się tylko na sobie, na swoim samopoczuciu, swoich umiejętnościach, swoich pragnieniach, bogaceniu się (Ruman 2011: 87).

Maria Łoś w przypadku wykorzystywania roli do pozazawodowych celów pisała o „manipulacji” rolą (Łoś 1985: 123-145), powyższy przykład pokazuje, że manipulacja rolą może być „wartością pozytywną”, jeśli jej skutek jest obiektywnie dobry (tamże). Inna jest wymowa owej manipulacji, jeśli aktor wykorzystuje rolę zawodową, popularność do realizacji partykularnych celów (np. próbuje uniknąć płacenia mandatu za przekroczenie prędkości).

Jedna z aktorek metaforycznie mówi o „szlachetnych fundamentach”, na jakich stara się budować swoje życie rodzinne i zawodowe. W jej przekonaniu nie jest odosobniona w środowisku w ukierunkowaniu swego życia na wartości duchowe:

\footnotetext{
Według mnie, warto budować swój świat i życie na szlachetnych fundamentach, w oparciu o wartości duchowe, jakkolwiek patetycznie to zabrzmi [...]. Znam wiele osób, które myślą podobnie. Myślę, że obraz mojego środowiska jest zdeformowany przez ludzi, którzy brak talentu rekompensują kontrowersyjnymi pozazawodowymi działaniami. Ale to mniejszość (A10: 40).
}

\section{Zamiast podsumowania}

Aktorzy buntują się niekiedy przeciwko wizerunkowi artysty, który jest „poza prawem boskim i ludzkim” (por. Golka 2012; Wejbert-Wąsiewicz 2009a, 2009b) i prowadzi niemoralne życie. To właśnie jest stereotyp, bowiem dziennikarze nie chcą pisać o twórcach „nudnych”, niezmieniających partnerów, nienadużywających alkoholu, niewywołujących skandali. Z drugiej strony, gdybyśmy chcieli poprzestać na analizie przekazów werbalnych, na sferze aktorskich deklaracji, uruchomilibyśmy „efekt aureoli”. Wnikliwa analiza społecznego świata teatru ukazuje środowisko aktorskie spolaryzowane, uwikłane w spory, konflikty, podzielone na kliki. Implikowane „pożądane stany rzeczy”, przekonania i zasady istotne dla jednostki czy zbiorowości, nie są tożsame z praktyką życia 
codziennego (logos nie zawsze jest tożsamy z etosem). Wartości negatywne (w ujęciu Kluckhohna) ${ }^{8}$ funkcjonują w życiu każdej zbiorowości. Socjolog zdaje sobie sprawę z rozbieżności pomiędzy wartościami deklarowanymi a realizowanymi i z uwikłania wartości w grę interesów. Marek Ziółkowski pisze:

Wartości rozumiane jako subiektywne cele implikują normatywną (aksjologiczną) orientację podmiotu działania: wartość jest celem uznawanym za słuszny, właściwy czy też usprawiedliwiony. Orientacji normatywnej można przeciwstawiać orientację utylitarną (instrumentalną, hedonistyczną), inaczej mówiąc - wartościom można przeciwstawić interes, czyli cel uznawany za korzystny. Różnice między tymi orientacjami są jednak kwestią stopnia. Każdy człowiek łączy w życiu obie te orientacje. Jeden obiekt może być jednocześnie i wartością, i interesem, ale interes nie zawsze jest wartością, a wartość nie musi być interesem; człowiek próbuje niekiedy realizować cele, które uważa za słuszne, lecz dla siebie niekorzystne (Ziółkowski 2002: 293).

W kontekście problemu społecznego funkcjonowania wartości Ziółkowski wspomina o formułach językowych, o społecznie akceptowanym dyskursie, np. na temat indywidualnej i zbiorowej tożsamości. Podjęte działania wyjaśniane są poprzez odwołania do społecznie podzielanych wartości, tymczasem często są to tylko „rytualne formuły”, za którymi de facto kryją się partykularne interesy. Prawdziwe przyczyny działań ukryte są pod warstwą maskujących eksplikacji, werbalnych formuł tworzących - mówiąc językiem Charlesa W. Millsa - ,słownik motywów". Aktorzy wspierający inicjatywy charytatywne (np. dużą popularnością cieszy się akcja „Świąteczna paczka”), współpracujący z fundacjami, czasem czynią to dla rozgłosu, ale pewnie wielu działa z potrzeby serca. Moim zdaniem, nie ma sensu wątpić w bezinteresowność ich intencji, jeśli wynika z tego działania obiektywne dobro. Clyde Kluckhohn w swojej typologii uwzględnił wymiar wyrazistości - wartości wyrażone explicite bądź implicite. Ciekawe, że w wypowiedziach aktorów nie ma mowy o wartościach materialnych, o dążeniu do wysokiego poziomu życia, są to z pewnością wartości implicytne, o których nie wypada mówić wprost (po pierwsze, według reguły savoir vivre’u dżentelmeni nie rozmawiają o pieniądzach; po drugie, w kręgu kultury chrześcijańskiej uznaje się bezwzględny prymat wartości duchowych nad materialnymi, trzeba więcej „być”

\footnotetext{
${ }^{8}$ Clyde Kluckhohn uwzględnił osiem wymiarów kategoryzacji wartości (wymiar modalności - wartości pozytywne bądź negatywne; wymiar treściowy - wartości estetyczne, poznawcze i moralne; wymiar intencji - wartości-środki, czyli wartości instrumentalne, oraz wartości-cele, czyli wartości autoteliczne bądź realizacyjne; wymiar ogólności - wartości ogólne i wartości szczegółowe (jednodziedzinowe); wymiar intensywności - wartości kategoryczne, preferencyjne oraz hipotetyczne; wymiar wyrazistości - wartości wyrażone explicite bądź implicite; wymiar zakresu - jednostkowe, grupowe i uniwersalne; wymiar organizacji - wartości izolowane i zintegrowane oraz wartości naczelne i pochodne) (Ziółkow ski 2002: 292). Nie jest to wyczerpująca systematyzacja, można dodać wymiar przestrzeni (wartości lokalne, ponadlokalne, globalne) i czasu (wartości archaiczne, tradycyjne, współczesne), wymiar substancjalny (wartości duchowe i materialne), wymiar trwałości (wartości stałe i zmienne).
} 
niż „mieć”, zatem w trosce o własny wizerunek, lepiej zastosować derywaty) ${ }^{9}$. W wywiadach aktorzy niewiele mówią o wartościach zmysłowych, hedonistycznych (przyjemnościach, życiu pełnym przygód i wrażeń), o jasnej stronie sławy, o popularności, która nie tylko nie udręcza, ale ma też walor utylitarny itd. Nie ulega wątpliwości, że wielu artystów w pełni korzysta z możliwości, jakie niesie ze sobą tzw. wolny rynek, wielu uczestniczy w komercyjnych projektach. Niewielu jest purystów, którzy intencjonalnie ograniczają się do satysfakcjonującej artystycznie, ale nieatrakcyjnej finansowo pracy etatowej na scenie.

Aktorzy, którzy są szczególnie zainteresowani aksjologicznym wymiarem życia zawodowego i rodzinnego, etyczne postępowanie uznają za swój największy sukces. Dostrzegają szerokie spectrum wartości, które w trajektorii ludzkiego doświadczenia mają charakter uniwersalny i modelują ich horyzont myślenia i działania:

Nie chcę robić rzeczy, z którymi ja się etycznie nie zgadzam. Kariera, sukces... to chyba to, że bez względu na to, w jakiej byłem sytuacji zawodowej, wszystko robiłem w zgodzie ze sobą i wszystko, do czego doszedłem, jest oparte na moim etycznym i moralnym kodeksie (Wywiad nr 10).

Barbara Mróz przywołuje dychotomiczny podział wartości T. Kassera (wartości wewnętrzne i zewnętrzne). Wewnętrzne to „samoakceptacja, przynależność i poczucie wspólnoty”, zewnętrzne natomiast to „sukces finansowy, chęć gromadzenia bogactwa, własności, wygląd i sława" (Mróz 2015: 51). Realizacja wartości z pierwszej kategorii nadaje życiu smak, sprzyja progresji i samorealizacji. Zdaniem Kassera, niemożność zaspokojenia psychologicznych potrzeb wewnętrznych decyduje o wzmożonym zainteresowaniu wartościami zewnętrznymi, które tylko na krótko dają zadowolenie ${ }^{10}$. Umiejętność znalezienia równowagi pomiędzy wartościami wewnętrznymi i zewnętrznymi jest istotna w każdym środowisku, nie tylko w społecznym świecie teatru. Jedna rzecz wydaje się warta podkreślenia - praca zawodowa stanowi dla zdecydowanej większości aktorów wartość autoteliczną, jest autentyczną pasją, spełnieniem, samorealizacją, a nawet sensem życia.

\section{Bibliografia}

\section{Aktorzy i reżyserzy - źródła prasowe}

A7: Piotr Fronczewski. Rozmowa z Kamilą Drecką, Czy jeszcze mam marzenia?, „Zwierciadło” 2015, styczeń, s. 54-61.

A10: Magdalena Stużyńska. Rozmowa z Martą Bednarską, Mniej znaczy więcej, „Twój Styl” 2014, listopad, s. 38-44.

A12a: Edyta Olszówka. Rozmowa z Marzeną Rogalską, Zawsze prosto w oczy, „Uroda Życia” 2015, sierpień, s. 16-22.

${ }^{9}$ Pojęcie derywatu według eksplikacji Vilfreda Pareto (1994).

${ }^{10} \mathrm{Z}$ rozważaniami T. Kassera (2002) ideowo kompatybilne są niemal wszystkie książki

E. Fromma (a szczególnie napisany w 1976 roku esej filozoficzny pt. Mieć czy być). 
A16: Leszek Lichota. Rozmowa z Beatą Pawłowicz, Kiedy bohater idzie na wojnę, „Zwierciadło” 2014, lipiec, s. 86-90.

A17: Katarzyna Zielińska. Rozmowa z Magdaleną Mołek, Kryśka i jej grafik, „Sens” 2014, październik, s. 6-12.

A18: Urszula Grabowska. Rozmowa z Aliną Gutek, Rośnie we mnie spokój, „Sens” 2011, marzec, s. $52-58$.

A19: Krzysztof Globisz. Wysłuchała Małgorzata Wach, Anioł też czlowiek, „Sens” 2011, marzec, s. 115.

A25: Anna Dereszowska. Rozmowa z Magdaleną Mołek, Trochę mi się w życiu pozmieniało, „Sens” 2014, lipiec, s. 6-11.

A26: Maciej Stuhr. Rozmowa z Hanną Halek, Delikatnie rzecz ujmując, „Sens” 2014, lipiec, s. 96-98.

A31: Jan Peszek. Rozmowa z Hanną Halek, Całe życie po swojemu, „Zwierciadło” 2014, maj, s. $96-101$.

A33: Katarzyna Maciąg. Rozmowa z Hanną Halek, Teraz mogę być każdym, „Sens” 2014, marzec, s. $42-45$.

A34: Kinga Preis. Rozmowa z Hanną Halek, Chcę czegoś więcej, „Zwierciadło” 2014, marzec, s. $42-49$.

A38b: Artur Barciś. Rozmowa z Justyną Kasprzak, Już nie mam kompleksów, http://kobieta.interia. pl/gwiazdy/wywiady/news-artur-barcis-juz-nie-mam-kompleksow [dostęp 10.08.2015].

A39b: Stanisława Celińska. Rozmowa z Jakubem Janiszewskim, Lubię zaczynać od nowa, „Uroda Życia” 2015, wrzesień, s. 46-50.

A41: Anna Korcz. Rozmowa z Agatą Młynarską, Spokojnie siedzę na brzegu, „Skarb” 2015, listopad, s. 24-27.

A47: Ilona Ostrowska. Rozmowa z Beatą Pawłowicz, Jestem twardzielka, „Zwierciadło” 2011, listopad, s. 44-48.

A52: Karolina Gruszka. Rozmowa z Izą Komendołowicz, Karolina postanawia wrócić, „Pani” 2016, luty, s. 24-33.

A55: Maja Ostaszewska. Rozmowa z Anną Serdiukow, Wolność kocham i rozumiem, „Zwierciadło” 2016, luty, s. 32-38.

R3: Agnieszka Glińska. Rozmowa z Maciejem Zienkiewiczem, Urządzanie siebie, „Sens” 2014, marzec, s. 54-57.

R5: Bodo Koks. Rozmowa z Magdaleną Żakowską, Moja walka, „Uroda życia” 2015, wrzesień, S. $52-55$.

\section{Inne źródła}

Dyczewski L. (2009), Wartości w kulturze, [w:] M. Filipiak (red.), Wprowadzenie do socjologii kultury, Wydawnictwo Uniwersytetu Marii Curie-Skłodowskiej, Lublin, s. 185-205.

Fromm E. (2012), Mieć czy być, tłum. J. Karłowski, Wydawnictwo Rebis, Warszawa.

Globisz K. (2015), Globisz odbiera telefon, http://wyborcza.pl/duzyformat/1,143522,17358380,G lobisz_odbiera_telefon.html [dostęp 23.07.2015].

Golka M. (2012), Socjologia artysty nowożytnego, plik PDF, Poznań 2012.

Ingarden R. (1972), Ksiązeczka o człowieku, Wydawnictwo Literackie, Kraków.

Jałowiecki S. (1978), Struktura systemu wartości. Studium zróżnicowań międzygeneracyjnych, PWN, Warszawa-Wrocław.

Janda K. (2015), Nie trzeba mnie zmieniać, [w:] Ł. Maciejewski, Aktorki. Portrety, Społeczny Instytut Wydawniczy Znak, Kraków, s. 139-177.

Kacperczyk A. (2016), Spoleczne światy. Teoria - empiria - metody badań. Na przyktadzie społecznego świata wspinaczki, Wydawnictwo Uniwersytetu Łódzkiego, Łódź.

Kasprzyk E., Kędziak M. (2013), MIŁ.OŚĆ, Wydawnictwo G+J Gruner+Jahr Polska Sp. z o.o. \& Co. Spółka Komandytowa, Warszawa. 
Kasser T. (2002), The High Price of Materialism, MIT Press, Cambridge.

Komunikat CBOS (sierpień 2005), Wartości i normy w życiu Polaków, BS/133/2005, oprac. R. Boguszewski.

Komunikat CBOS (2010), Co jest ważne, co można, a czego nie wolno - normy $i$ wartości w życiu Polaków, BS/99/2010, oprac. R. Boguszewski.

Kuszewska M., Warto, „Pani” 2015, wrzesień, s. 64.

Łabonarska H. (2015), Chcę być świętą. Halina Łabonarska w rozmowie z Barbarą Gruszka-Zych, „Gość Niedzielny”, nr 39 (z 27.09).

Łoś M. (1985), Role społeczne w nowej roli, [w:] E. Mokrzycki, M. Ofierska, J. Szacki (red.), O społeczeństwie i teorii społecznej. Księga pamiątkowa S. Ossowskiego, PWN, Warszawa, s. $123-145$.

Mróz B. (2008), Osobowość wybitnych aktorów polskich. Studium różnic międzygeneracyjnych, Wydawnictwo Naukowe Scholar, Warszawa.

Ossowska M. (1985), Normy moralne. Próba systematyzacji, PWN, Warszawa.

Ossowski S. (1967), Konflikt niewspólmiernych skal wartości, [w:] tenże, Z zagadnień psychologii spolecznej, Wydawnictwo Naukowe PWN, Warszawa, s. 71-101.

Pareto V. (1994), Uczucia i działania. Fragmenty socjologiczne, thum. M. Dobrowolska, M. Rozpędowska, A. Zinserling, PWN, Warszawa.

Ruman E. (2011), Główna rola w teatrze życia, Fronda, Warszawa.

Scheler M. (2004), Wolność, miłość, świętość, tłum. G. Sowiński, Wydawnictwo Znak, Kraków.

Tatarkiewicz W. (1986), Pojęcie wartości, [w:] tenże, O filozofii i sztuce, PWN, Warszawa, s. 69-78.

Tatarkiewicz W. (1990), Historia filozofii, t. III, PWN, Warszawa.

Wejbert-Wąsiewicz E. (2009a), Kim jest artysta?, „Dwumiesięcznik społeczno-polityczny. Realia i co dalej...", nr 3 (12), s. 122-132.

Wejbert-Wąsiewicz E. (2009b), Rola artysty w społeczeństwie, „Dwumiesięcznik społeczno-polityczny. Realia i co dalej...", nr 4 (13), s. 109-120.

Zapasiewicz Z. (1989), Czas wyboru, [w:] A. Roman, M. Sabata (red.), Komedianci - rzecz o bojkocie, AWP MOST, Warszawa, s. 236-243.

Ziółkowski M. (2002), Wartości, [w:] Encyklopedia socjologii, t. 4, Oficyna Naukowa, Warszawa, s. 289-297.

\section{Emilia Zimnica-Kuzioła}

\section{RELEVANT VALUES IN THE WORLD OF ACTORS OF POLISH PUBLIC DRAMATIC THEATERS IN THE LIGHT OF SELECTED CLASSIFICATIONS}

Summary. The aim of the article is to analyze the statements of actors of Polish public dramatic theaters, which is to lead to the reconstruction of the axiological system that directs their actions. The theoretical framework is determined by the typology of values proposed by the Max Scheler's phenomenology representative (hedonistic, vital, spiritual, cognitive, aesthetic and moral-religious values) (Scheler 2004; Tatarkiewicz 1990: 219). Leon Dyczewski developed the Scheler typology, adding material and sociocentric values (Dyczewski 2009: 193). Such thematic arrangement allowed me to indicate the values that are important both in the personal and professional life of Polish theater artists. I used both existing sources (published journalistic interviews with actors and directors) as well as induced (free interviews conducted by me with Polish actors).

Key words: actors of Polish public theaters, values as the direction of aspirations and actions inducted by me with Polish actors. 